\title{
BELFAST RADIOCARBON DATES IX
}

\author{
G W PEARSON
}

Palaeoecology Laboratory, Queen's University, Belfast, Northern Ireland INTRODUCTION

The dating equipment and operating conditions remain essentially as described in $\mathrm{R}, 1970, \mathrm{v} 12$, p 285-286, except that the samples are now measured at either 76,152 or $380 \mathrm{~cm} \mathrm{Hg}$ at $20^{\circ} \mathrm{C}$ to allow for the variation in sample size. The calculation of results and correction for isotopic enrichment remain as previously described in R, 1973, v 15, p 212.

The pretreatment of charcoal samples is as described in $\mathrm{R}, 1973$, $\mathrm{v}$ 13, p 103, and wood sample pretreatment is as described in R, 1973, $\mathrm{V} 15$, p 212. The pretreatment given to peat samples is dependent upon the fraction separated, the nomenclature used for the various fractions is given in $\mathrm{R}, 1971, \mathrm{v} 13, \mathrm{p}$ 123. The chemical treatment for fractions $\mathrm{A}$, $\mathrm{C}$ and $\mathrm{F}$ follows that recommended by Dresser 1970 and can be summarized as follows:

Fraction A: Whole peat

The sample is dispersed in a $1 \% \mathrm{HCl}$ solution inside a Buchner flask and evacuated until the evolution of $\mathrm{CO}_{2}$ stops. The sample is then thoroughly washed in distilled water, dried, and if sufficiently large, charred in a muffle furnace at $500^{\circ} \mathrm{C}$.

Fraction C: Base-soluble, acid-insoluble component (humic acid)

The sample was dispersed in a $1 \%$ solution of $\mathrm{NaOH}$ for $24 \mathrm{hrs}$, then centrifuged and the supernatant acidified with $1 \% \mathrm{~V} / \mathrm{V} \mathrm{HCl}$. The resulting precipitate was separated by centrifuging, washed and recentrifuged, then dried, before charring in a muffle furnace at $500^{\circ} \mathrm{C}$.

Fraction F: Fine particulate $<250 \mu$ in size.

Sample was dispersed in a $1 \%$ solution of $\mathrm{NaOH}$ for $24 \mathrm{hrs}$, then centrifuged and the supernatant discarded. The sample was resuspended in distilled water, centrifuged and the supernatant discarded; this stage was repeated until the supernatant became clear. The residue was filtered through a $250 \mu$ sieve and the filtrate passed through a continuous flow centrifuge at 9000 to $12,000 \mathrm{rpm}$ at a flow rate of $200 \mathrm{ml}$ per minute. The sediment was suspended in a $1 \% \mathrm{HCl}$ solution and centrifuged; after washing the sediment with distilled water, the sample was recentrifuged before drying and if sufficiently large, charred at $500^{\circ} \mathrm{C}$.

All bone samples were first cleaned before washing in $\mathrm{NaOH}$ to remove any humic acid, etc, then reduced to small fragments before being loaded into a Buchner flask containing a $<1 \mathrm{~N} \mathrm{HCl} \mathrm{solution.} \mathrm{The}$ pressure was reduced to $10 \mathrm{~cm} \mathrm{Hg}$ the acid being regularly replaced until the bone had been reduced to a soft spongy tissue, ie, collagen. The collagen was then washed with a $1 \% \mathrm{NaOH}$ solution, centrifuged, followed by a second wash with $5 \% \mathrm{HCl}$ solution, and recentrifuged. The collagen was then boiled in distilled water and centrifuged whilst hot to remove any insoluble material. The supernatant was then dried. 
All samples are from Ireland unless stated otherwise. All samples without $\delta^{13} C$ values are assumed to be $=-25.0 \%$.

\section{ACKNOWLEDGMENTS}

I am very grateful to $\mathrm{C}$ Holland and Prof and Mrs W Kirk for permission to use in this list (II Palaeoecologic A) samples extracted from the PhD thesis (Queen's Univ, Belfast) of the late Sarah M Holland (lecturer in Geography, Queen's Univ, Belfast).

I wish to thank Mrs F Qua and other technicians who have carried out the pretreatments and routine operation of the counting equipment. My thanks also to the Ministry of Finance and the Ulster Museum whose financial assistance helps to support research within the laboratory and to each person who submitted samples, for their cooperation in the preparation of this report.

I. ARCHAEOLOGIC SAMPLES

\section{Quoyscottie series, Orkney, Scotland}

Charcoal samples from cremations, taken from turf and subsoil construction of burial mounds at Quoyscottie, 20km NW Kirkwall, Orkney, Scotland (59 $5^{\circ}$ N, $3^{\circ} 13^{\prime} \mathrm{W}$, NGR: HY 302227). Coll Apr 1976 by M Hedges; subm Nov 1976 by P J Ashmore, Inspector, Ancient Monuments, Scottish Development Dept, Scotland.

UB-2158. QS 76 F15 r $\begin{array}{r}\mathbf{2 8 5 0} \pm \mathbf{4 0} \\ \delta^{1.8} C=-25.0 \%\end{array}$

Charcoal. All Betula sp except 1 small fraction of Pinus sp.
UB-2161. QS 76 F103
$3145 \pm 120$
$\delta^{1 s} C=-24.4 \%$ o

Charcoal. Eight-year-old branch of Corylus sp cut in early summer.

UB-2162. QS 76 F64

$2940 \pm 85$

Charcoal. Corylus sp, twigs and small branches.

UB-2163. QS 76 F91

$$
\begin{array}{r}
2660 \pm \mathbf{1 5 0} \\
\delta^{1 s} C=-23.8 \%
\end{array}
$$
branches.

Charcoal. Betula sp, 2 pieces could have been from substantial

General Comment (PJA): dates are for a group of small burial mounds and assoc flat cemetery similar to many others in Orkney. They are close to those from some burnt mounds (habitation sites covered and preserved by pot boilers) and do not clash with contention that burnt mounds and burial mounds were made by 1 cultural group.

Sp id by J R Pilcher, Paleoecol Lab, Queen's Univ, Belfast. Comment (JRP): all observed charcoal samples were from sp native to British Isles and were generally from small branches, suggesting that they originated from Orkney. Only 1 small fragment of soft wood (Pinus) may have had different origin, possibly driftwood. 
Clogher series, Co Tyrone

Samples from settlement complex, including Hill-fort and Ring-fort in Clogher Demesne, 29km WSW of Dungannon, Co Tyrone $\left(54^{\circ} 24^{\prime} \mathrm{N}\right.$, $7^{\circ} 9^{\prime}$ W, IGR: H 545512) alt, 100m. Samples coll and subm 1969, 1971-5, 1977 by R B Warner, Ulster Mus, Belfast).

\section{UB-835. C1 576}

$$
\begin{array}{r}
1515 \pm 120 \\
\delta^{13} C=-23.0 \% 0
\end{array}
$$

Charcoal, subm 1973. From Trench A.3 Layer A.3. Primary silting of Ringditch.

UB-837. C1 710

$$
\begin{array}{r}
\mathbf{3 0 4 5} \pm \mathbf{7 5} \\
\delta^{13} C=-24.1 \% \text { \% }
\end{array}
$$

Charcoal, subm 1973. From Trench F.1. Old soil, sealed by debris derived from construction of 'mound'.

\section{UB-838. C1 514}

$$
\begin{array}{r}
1770 \pm 65 \\
\delta^{13} C=-24.7 \%
\end{array}
$$
fill.

Charcoal, subm 1973. From Trench A.3, Layer Y.7. Early Ring-ditch

UB-839. C1 285

$$
\begin{array}{r}
2630 \pm 45 \\
\delta^{13} C=-24.4 \% \text { o }
\end{array}
$$

Charcoal, subm 1973. From Trench A.3, Pit F.2, base. Comment (RBW): probably a post, see also UB-840.

UB-840. C1 284

$$
\begin{array}{r}
2420 \pm 100 \\
\delta^{13} C=-24.7 \%
\end{array}
$$

Charcoal, subm 1973. From Trench A.3, Pit F.2, top. Comment (RBW): part of post, perhaps contaminated by occupation. See also UB-839.

\section{UB-841. C1 425}

$$
\begin{array}{r}
1770 \pm \mathbf{9 0} \\
\delta^{13} C=-25.2 \%
\end{array}
$$

Charcoal, subm 1973. From Branch or sapling of ca 50 yr growth. Trench A.3, Layer Y4b/5. Later Ring-ditch fill.

UB-842. C1 332

$$
\begin{array}{r}
1635 \pm 65 \\
\delta^{13} C=-24.6 \%
\end{array}
$$

Charcoal, subm 1973. From Trench A.3. Late Ring-fort occupation.

UB-844. C1 989

$$
\begin{array}{r}
\mathbf{1 5 5 5} \pm \mathbf{4 5} \\
\delta^{13} C=-24.6 \% 0
\end{array}
$$

Finely dispersed charcoal, subm 1973. From Trench R.2. Charcoal layer assoc with iron smelting furnace.

UB-2033. C1 2050, 2201, 2461, 2598

$$
\begin{array}{r}
1725 \pm 115 \\
\delta^{1 s} C=-24.3 \%
\end{array}
$$

Charcoal, subm 1975. From Trench X.1, Layer B.8. Duplicate sample UB-2034. 
UB-2034. C1 2050, 2201, 2461, 2598

$$
\begin{array}{r}
1670 \pm 70 \\
\delta^{13} C=-24.7 \%
\end{array}
$$

Charcoal, subm 1975. Trench X.1, Layer B.8. Duplicate sample UB-2033. Comment (RBW): dates for UB-2033 and -2034 agree closely, weighted mean calculated to give $1685 \pm 60$. Late Ring-ditch fill.

UB-2035. C1 1906, 1909, 2597 and 2719

$$
\begin{array}{r}
1440 \pm 45 \\
\delta^{13} C=-24.4 \%
\end{array}
$$

Charcoal, subm 1975. From Trench X.1, Layer B.6. Early Ring-fort occupation.

\section{UB-2036. C1 2700}

$$
\begin{array}{r}
\mathbf{1 7 1 0} \pm \mathbf{7 5} \\
\delta^{13} C=-27.2 \%
\end{array}
$$

Charcoal, subm 1975. From Trench X.1, Layer B.12. Earliest Ringditch fill.

\section{UB-2037. C1 2650}

$$
\begin{array}{r}
2185 \pm \mathbf{4 5} \\
\delta^{13} C=-24.9 \%
\end{array}
$$

Charcoal, subm 1975. From Trench X.1, Layer B.9. Mid Ring-ditch fill.

$\begin{array}{lll}\text { UB-2038. C1 } 1922 & 1260 \pm 70\end{array}$

Charcoal, subm 1975. From Trench X.1, Layer B.7. Ring-fort occupation.

\section{UB-2175. C1 2733}

$$
\begin{array}{r}
\mathbf{2 6 4 0} \pm \mathbf{4 5} \\
\delta^{13} C=-23.8 \% \text {. }
\end{array}
$$

Charcoal, subm Apr 1977. From Trench S.5, Layer 'P'. Charcoal spread on artificial platform (field?) cut by plough-marks.

\section{UB-2176. C1 3320}

$$
\begin{array}{r}
1335 \pm \mathbf{6 5} \\
\delta^{13} C=-25.0 \%
\end{array}
$$

Charcoal, subm Apr 1977. From Trench RB.1. Layer of quartz pebbles in Ring-barrow ditch.

General Comment (RBW): UB-837 ante-dated construction of inauguration mound, and probably belongs to 1 of scatters of prehistoric occupation on hill. UB-839, -840, and -2175 suggest later Bronze-age phase of occupation, to which belongs otherwise undatable coarse ware. UB-835, $-838,-841,-2034,-2036$, and -2037 belong to Ring-ditch, with which is assoc Late- and sub-Roman imported material and Irish material of Later Iron-age date. UB-842, -2035, and -2038 belong to Ring-fort, overlying Ring-ditch with which is assoc imports of Post-Roman date. UB2037 may be derived from Earlier Iron-age occupation. UB-844 places a bowl-furnace into Later Iron age, and UB-2176 shows 're-use' of Ringbarrow in Later Iron-age times. As far as phases can be dated artifactually, ${ }^{14} \mathrm{C}$ dates are consistent with other evidence. 


\section{Dunsilly Motte series, Co Antrim}

Samples from Rath, $3 \mathrm{~km} N$ of Antrim, Co Antrim $\left(54^{\circ} 44^{\prime} \mathrm{N}, 6^{\circ}\right.$ 14' W, IGR: J 141890) alt, 30m. Samples coll and subm 1974-75 by T McNeill, Archaeol Dept, Queen's Univ, Belfast (McNeill, 1975).

\section{UB-967. Sample 1}

$1905 \pm 75$

$\delta^{13} C=-24.9 \%$ M29.

Very fine charcoal coll and subm 1974 from Pre-rath B Occupation

UB-968. Sample 2

$890 \pm 40$

$\delta^{13} C=-25.3 \%$

Charcoal coll and subm 1974 from stained earth built up against inner side of house wall.

\section{UB-2001. Sample 3}

$1565 \pm 105$

$\delta^{13} C=-25.3 \%$

Charcoal coll and subm 1975 from external hearth. Sp (Quercus, Alnus, Corylus) id by J Hillam, Dept Prehistory \& Archaeol, Univ Sheffield, England. Pre-rath Period C.

\section{UB-2002. Sample 4}

$$
\begin{array}{r}
1380 \pm 65 \\
\delta^{13} C=-24.4 \% 0
\end{array}
$$

Charcoal from same layer as UB-967, coll and subm 1975. Comment: UB-967 and $-2002{ }^{14} \mathrm{C}$ dates are not close enough for reliable date for Pre-rath B occupation or consistent with archaeol evidence that these originate from same layer, unless UB-967 contains fossil wood charcoal or UB-2002 is contaminated by younger material.

General Comment (TM): site history (TM, 1975-76) is of 3 pre-rath periods and 3 rath periods of uninterrupted occupation. Construction of a motte followed abandonment within the old earthworks ca AD 1200: all periods post-date introduction of souterrain ware. UB-967 and -2002 are from same charcoal occupation spread of period pre-rath B: UB-2001 from succeeding pre-rath $\mathrm{C}$ period. UB-968 comes from occupation charcoal on floor of rath III house. If we reject UB-967 as contaminated by burning fossil timber, we would arrive at date, ca AD 600-700 for rath construction with occupation lasting, through 3 periods, for ca 200 to $300 \mathrm{yr}$, entirely compatible with other sites.

\section{Ballacagen series, Isle of Man}

Oak wood samples from Ballacagen ca $1 \mathrm{~km}$ NW of Castletown, Isle of Man (54 $5^{\prime} \mathrm{N}, 4^{\circ} 40^{\prime} \mathrm{W}$, NGR: SC 259685). Samples coll 1941-44 by the late Gerhard Bersu (1977); subm Oct 1975 by A M Cubbon, The Manx Mus, Douglas, Isle of Man.

UB-2027. Site A

Cellulose extracted from wood and charred.
$2155 \pm 75$

$\delta^{1 s} C=-24.3 \%$ 
UB-2028. Site B

$2235 \pm 45$

$\delta^{13} C=-24.8 \%$ o

Cellulose extracted from wood and charred.

General Comment (AMC): samples are from remains of circular timberbuilt houses. Wood was well preserved because of generally damp conditions of area. Different phases of major rebuilding were id. Finds confirm dating of houses to Iron age.

\section{Drigg Hearth series, Cumbria, England}

Charcoal from hearth in peat at Drigg, $3 \mathrm{~km} \mathrm{~S}$ of Seascale, Cumbria (54 $20^{\prime} \mathrm{N}, 3^{\circ} 30^{\prime} \mathrm{W}$, NGR: 305499 ) alt, $2 \mathrm{~m}$. UB-905 coll by W Tutin, Univ Leicester, England, and UB-906 coll by $\mathrm{J}$ Ward and subm by $\mathrm{J}$ Cherry, Seascale.

\section{UB-905. Drigg Hearth A}

Charcoal from Drigg Hearth.

UB-906. Drigg Hearth A

Charcoal from Drigg Hearth.

General Comment (JC): hearth was exposed ca 1969 by erosion of low sea-cliff at Drigg. Hearth consisted of lens of heat-shattered stones mixed with charcoal and embedded in narrow band of peat. Hearth measurements were $3 \mathrm{~m} \times 0.3 \mathrm{~m}$.

\section{Tallington Round Barrow series, Cambridgeshire, England}

Samples from round barrow at Tallington, $7.2 \mathrm{~km}$ ENE Stamford,

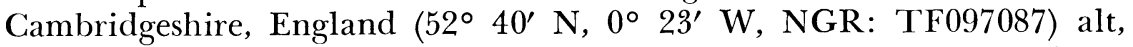
$13 \mathrm{~m}$. Site excavated by W G Simpson, Archaeol Dept, Univ Nottingham, England, for Welland Valley Research Comm (Simpson, 1976). Samples coll 1965 and subm 1970 by WGS. Human bones id by Duchworth Lab of Physical Anthropol, Cambridge, England.

UB-450. Tal 16 EU.1.4.89

$$
\begin{array}{r}
\mathbf{3 4 1 0} \pm \mathbf{1 6 5} \\
\delta^{13} C=-21.6 \%
\end{array}
$$

Collagen fraction of human bones from bottom of primary grave in center of barrow. Comment (WGS): sample assoc with Yorkshire-type food vessel which, in decorative details, resembles certain Irish examples.

\section{UB-452. Tal 36}

$$
\begin{array}{r}
\mathbf{2 4 2 5} \pm \mathbf{1 3 5} \\
\delta^{1 s} \mathrm{C}=-30.0 \%
\end{array}
$$

Wood from bottom of pit alignment of 'boundary work' at Tallington. Comment (WGS): no dating evidence has yet been obtained for such pit alignment boundary works, common on gravel lands of SE England.

UB-453. Tal 17

$2675 \pm 100$

'Fossil burial'. Collagen fraction of human bones from various levels of grave above final burial. Comment (WGS): sample assoc with longnecked Beaker and pair of copper earrings. 
UB-455. Maxey, Iron age enclosure

$$
\begin{array}{r}
\mathbf{2 5 4 5} \pm \mathbf{1 3 0} \\
\delta^{13} C=-23.3 \% \text { o }
\end{array}
$$

Collagen fraction of animal bones from Iron age enclosure at Maxey, $8 \mathrm{~km} \mathrm{E}$ of Stamford, Cambridgeshire, England $\left(52^{\circ} 39^{\prime} \mathrm{N}, 0^{\circ} 22^{\prime} \mathrm{W}\right.$, NGR: TF115080) alt, 12m. Sample from Level 9 of Pit 18. Coll by M W Ponsford, City Mus Bristol, England; subm 1971 by WGS. Comment (WGS): sample should give terminus ante quem for pit alignment boundary work, not previously dated, and also date 1st phase of settlement on site.

\section{UB-456. Maxey, Neolithic henge monument}

$$
\begin{array}{r}
\mathbf{2 6 2 5} \pm \mathbf{2 7 5} \\
\delta^{13} C=-23.1 \% \text { o }
\end{array}
$$

Collagen fraction of animal bones from Neolithic 'Henge' monument at Maxey. Sample from S half of inner ditch of 'Henge' I. Coll 1966 and subm 1971 by WGS. Comment (WGS): no early site of this type has yet been radiocarbon dated. Site has particular importance as it produced a group of unique carved and painted antlers.

\section{Barholm series, Stamford, Cambridgeshire, England}

Samples from Neolithic settlement at Barholm, $8 \mathrm{~km}$ NE of Stamford, Cambridgeshire (52० $41^{\prime} \mathrm{N}, 0^{\circ}$ 22' E, NGR: TF101102) alt, $12 \mathrm{~m}$. Coll 1965 by V B Bishop, Royal Comm Ancient Monuments, and subm 1971 by WGS.

\section{UB-457. Pit 4}

$4305 \pm 130$

Charcoal from bottom of pit. Comment (WGS): dates late phase of settlement assoc with Grooved Ware, immediately prior to 1st appearance of Beaker pottery.

\section{UB-458. Pit 16}

$$
\begin{array}{r}
4255 \pm 135 \\
\delta^{13} C=-22.0 \%
\end{array}
$$

Collagen extraction from animal bones from all levels of small pit $0.5 \mathrm{~m}$ deep and $1 \mathrm{~m}$ in diam.

\section{PALAEOECOLOGIC SAMPLES A}

At all sites investigated exposures of peat stratigraphy were examined and sampling point determined. Peat monoliths, $1 \mathrm{~m}$ long, were extracted in $10 \mathrm{~cm}$ or $15 \mathrm{~cm} \mathrm{sq} \mathrm{sec} \mathrm{aluminium} \mathrm{boxes.} \mathrm{Each} \mathrm{monolith} \mathrm{was}$ then sealed in polythene to protect sample from possible contamination during transportation to lab. After pollen samples had been taken, exterior of same monolith was cleaned by cutting thin layer of peat from outer surfaces. Then series of peat slices, $1 \mathrm{~cm}$ or $0.5 \mathrm{~cm}$ thick, were cut along length of monolith, and each sample was sealed in polythene bag.

Unless stated otherwise, all samples were coll and subm by $\mathrm{S} M$ Holland (1975). 


\section{Butter Mt Monolith series, Co Down}

Samples of blanket peat from near summit of Butter Mt, $10 \mathrm{~km} \mathrm{SW}$ of Castlewellan, Co Down (54 $14^{\circ} \mathrm{N}, 6^{\circ} 2^{\prime} \mathrm{W}$, IGR: J275283) alt, ca $490 \mathrm{~m}$. Stratigraphic depths are below present bog surfaces.

UB-933. 24, to $25 \mathrm{~cm}$

$$
\begin{array}{r}
1205 \pm 65 \\
\delta^{13} C=-25.9 \% \%
\end{array}
$$

'F' fraction of blanket peat. Heath pollen values low, grass pollen values high, as hazel curve increases.

UB-934. 60 to $61 \mathrm{~cm}$

$$
1505 \pm 40
$$

$\delta^{13} C=-26.2 \%$

'F' fraction of blanket peat. Final decline of elm pollen. Restart of continuous plantain curve.

UB-935. 92 to $93 \mathrm{~cm}$

$$
\begin{array}{r}
\mathbf{2 2 3 5} \pm \mathbf{7 0} \\
\delta^{13} \mathrm{C}=-26.7 \%
\end{array}
$$

'F' fraction of blanket peat. Hazel curve rises, and heath pollen values decline.

UB-936. 124 to $125 \mathrm{~cm}$

$$
\begin{array}{r}
\mathbf{3 2 7 0} \pm \mathbf{4 5} \\
\delta^{13} C=-26.7 \% 0
\end{array}
$$

'F' fraction of blanket peat. Base of organic deposit. Grass curve falling, heath curve rising.

\section{Lacken II Monolith series, Co Down}

Samples from raised bog near Lackan, 6km NE of Rathfriland, Co Down (54 $16^{\prime} \mathrm{N}, 6^{\circ} 6^{\prime} \mathrm{W}$, IGR: J235374) alt, ca $75 \mathrm{~m}$. Stratigraphic depths are below present bog surface.

UB-875. 18 to $19 \mathrm{~cm}$

$$
\begin{array}{r}
1535 \pm \mathbf{4 5} \\
\delta^{1.3} C=-26.5 \%
\end{array}
$$

Sphagnum peat. 'A' fraction. Increased pollen values for ruderals and plantain. Cereal-type pollen present.

\section{UB-876. 43 to $44 \mathrm{~cm}$}

$$
\begin{array}{r}
2065 \pm 40 \\
\delta^{1.3} C=-26.8^{\%} \%
\end{array}
$$

Sphagnum peat. 'A' fraction. Decreased values for hazel and heath pollen, increased values for grass and plantain pollen. Cereal-type pollen present.

\section{UB-877. 59 to $60 \mathrm{~cm}$}

$$
\begin{array}{r}
\mathbf{2 2 4 5} \pm \mathbf{5 0} \\
\delta^{13} C=-26.5 \% 0
\end{array}
$$

Sphagnum peat. 'A' fraction. Birch, grass and sedge pollen values decrease. Substantial rise of heath pollen curve. Cereal-type pollen present. 
UB-878. 78 to $79 \mathrm{~cm}$

$$
\begin{array}{r}
\mathbf{2 9 6 0} \pm \mathbf{5 0} \\
\delta^{1 s} C=-26.3 \% \text { o }
\end{array}
$$

Sphagnum peat. 'A' fraction. Decrease of tree pollen values. Rise of heath pollen curve. Plantain and cereal-type pollen present.

UB-879. 102 to $103 \mathrm{~cm}$

$$
\begin{array}{r}
2990 \pm \mathbf{4 5} \\
\delta^{13} C=-26.3 \% \text { o }
\end{array}
$$

Sphagnum peat. 'A' fraction. Decrease of birch and hazel pollen curves. Increase of grass pollen values and beginning of rise of heath pollen values. Plantain and cereal-type pollen present.

UB-880. 116 to $117 \mathrm{~cm}$

$$
\begin{array}{r}
\mathbf{3 3 2 0} \pm \mathbf{5 5} \\
\delta^{13} C=-26.7 \% \text { o }
\end{array}
$$

Sphagnum peat. 'A' fraction. Calculation of pollen percentages, excluding localized influence of birch, indicates substantial rise of grass pollen values. Plantain and cereal-type pollen present.

UB-881. 125 to $126 \mathrm{~cm}$

$$
\begin{array}{r}
\mathbf{3 4 4 5} \pm \mathbf{4 5} \\
\delta^{13} C=-26.3 \% \text { o }
\end{array}
$$

Sphagnum peat. 'A' fraction. Increase in values of hazel and heath pollen, decrease in values of oak and birch pollen.

\section{UB-882. 150 to $152 \mathrm{~cm}$}

$$
\begin{array}{r}
\mathbf{3 6 4 0} \pm \mathbf{5 0} \\
\delta^{13} C=-26.2 \% \text { o }
\end{array}
$$

Sphagnum peat. 'A' fraction. Birch pollen values increase, oak pollen values decrease. Beginning of continuous curve for plantain pollen.

\section{UB-883. 168 to $169 \mathrm{~cm}$}

$$
\begin{array}{r}
3985 \pm \mathbf{4 5} \\
\delta^{13} C=-26.6 \%
\end{array}
$$

Sphagnum peat. 'A' fraction. End of continuous pollen curve for pine and elm. Decrease in oak pollen values, grass pollen curve begins to rise. Sporadic occurrence of plantain pollen.

\section{UB-884. 196 to $197 \mathrm{~cm}$}

$$
\begin{array}{r}
4520 \pm 50 \\
\delta^{13} C=-27.1 \% \text { o }
\end{array}
$$

Sphagnum peat. 'A' fraction. Basal date for pollen diagram to provide linkage with pollen diagram compiled for Lacken I Monolith series, R, 1975, v 17, p 231-233 (Holland, 1975).

\section{Lackan III Monolith, Co Down}

UB-911. 24 to $25 \mathrm{~cm}$

$$
\begin{array}{r}
2850 \pm 45 \\
\delta^{13} C=-23.9 \% o
\end{array}
$$

Sphagnum peat. 'A' fraction. Sample was dated to obtain age estimate of present bog surface at site close to Lackan II Monolith series, in attempt to find more recent surface level.

\section{Slievenaslat Monolith series, Co Down}

Samples from upland bog, $2 \mathrm{~km}$ NW of Castlewellan, Co Down $\left(54^{\circ} 21^{\prime} \mathrm{N}, 5^{\circ} 59^{\prime} \mathrm{W}\right.$, IGR: J329378) alt, ca $300 \mathrm{~m}$. Stratigraphic depths are below present bog surface. 
Sphagnum peat. ' $F$ ' fraction. Decrease of tree pollen, increase of grass pollen values. Plantain and cereal type pollen present.

\section{UB-897. 64, to $65 \mathrm{~cm}$}

$$
\begin{array}{r}
\mathbf{2 5 9 5} \pm \mathbf{7 0} \\
\delta^{13} C=-26.2 \% \text { 。 }
\end{array}
$$

Sphagnum peat with wood. 'F' fraction. Grid sample for compilation of deposition rate.

\section{UB-898. 100 to $101 \mathrm{~cm}$}

$$
\begin{array}{r}
\mathbf{2 8 1 0} \pm \mathbf{5 0} \\
\delta^{13} \mathrm{C}=-25.9 \% \text { \% }
\end{array}
$$

Sphagnum peat with wood. 'F' fraction. Tree pollen values decrease, heath pollen values increase. Plantain and cereal-type pollen present.

UB-899. 144 to $145 \mathrm{~cm}$

$$
\begin{array}{r}
3355 \pm \mathbf{4 5} \\
\delta^{13} C=-25.9 \% \text { o }
\end{array}
$$

Sphagnum peat with wood. 'F' fraction. Heath pollen values decrease. plantain and cereal-type pollen values increase.

\section{UB-900. 202 to $203 \mathrm{~cm}$}

$$
\begin{array}{r}
\mathbf{4 5 1 0} \pm \mathbf{9 5} \\
\delta^{13} C=-27.0 \%
\end{array}
$$

Reedswamp peat with wood. 'F' fraction. Tree pollen values decrease, grass pollen values increase. Cereal-type pollen present.

\section{UB-901. 230 to $231 \mathrm{~cm}$}

$$
\begin{array}{r}
4485 \pm 75 \\
\delta^{13} C=-26.8 \% o
\end{array}
$$

Reedswamp peat with wood. ' $F$ ' fraction. Decrease in oak pollen curve, increase of heath pollen values. Plantain and cereal-type pollen present.

\section{UB-902. 260 to $261 \mathrm{~cm}$}

$$
\begin{array}{r}
\mathbf{4 6 5 5} \pm \mathbf{6 0} \\
\delta^{13} C=-27.0 \% \text {. }
\end{array}
$$

Reedswamp peat with wood. 'F' fraction. Rise of oak pollen curve, decrease of alder pollen values. Plantain and cereal-type pollen present.

\section{UB-903. 300 to $301 \mathrm{~cm}$}

$$
\begin{array}{r}
\mathbf{5 8 1 5} \pm \mathbf{\pm 9 5} \\
\delta^{13} C=-26.8 \% \text { o }
\end{array}
$$

Fine detritus mud. ' $F$ ' fraction. Basal sample assoc with max values for pine pollen.

General Comment: these dates, together with those pub in R, 1975, v 17, p 226-238, Sec II, sites:-Slieve Croob, Lackan Monolith I and Carrivmoragh Monolith, constitute series discussed in detail in Holland (1975).

\section{Garry Bog series, Co Antrim}

\section{PALAEOECOLOGIC SAMPLES B}

Samples from raised bog, $3 \mathrm{~km} \mathrm{~N}$ of Ballymoney, Co Antrim $\left(55^{\circ} 6^{\prime}\right.$ N, $6^{\circ} 32^{\prime}$ W, IGR: 935314) alt, 46m. Coll Oct 1976 by R A Larmour, J R 
Pilcher, and P Blackstock, Palaeoecol Lab, Queen's Univ, Belfast. Subm Feb 1977 by RAL. Samples received 'A' fraction pretreatment and depths were measured from present bog surface.

\section{UB-2187. 126 to $134 \mathrm{~cm}$}

Sphagnum peat.

\section{UB-2188. 222 to $230 \mathrm{~cm}$}

Sphagnum peat. Increase in oak pollen.

\section{UB-2189. 238 to $246 \mathrm{~cm}$}

Sphagnum peat. Marked decline of oak pollen.

UB-2190. 366 to $374 \mathrm{~cm}$

$$
\begin{array}{r}
1045 \pm 65 \\
\delta^{13} C=-24.8 \% o
\end{array}
$$

$$
\begin{array}{r}
\mathbf{2 3 6 5} \pm \mathbf{7 0} \\
\delta^{13} C=-25.3 \%
\end{array}
$$

$$
\begin{array}{r}
\mathbf{2 5 5 5} \pm \mathbf{7 0} \\
\delta^{13} C=-24.7 \% 0
\end{array}
$$

$4025 \pm 85$ $\delta^{13} C=-25.6 \%$ 。 pollen.

Sphagnum peat. Decline of pine pollen and 2nd decline of elm

\section{UB-2191. 462 to $470 \mathrm{~cm}$}

$$
\begin{array}{r}
4590 \pm \mathbf{8 5} \\
\delta^{13} C=-25.9 \%
\end{array}
$$

Sphagnum peat. Market decline of elm pollen and at level of 1 st cereal and plantain pollen.

\section{UB-2192. 534 to $542 \mathrm{~cm}$}

$$
\begin{array}{r}
\mathbf{5 2 9 0} \pm \mathbf{7 0} \\
\delta^{13} C=-26.5 \% \text { \% }
\end{array}
$$

Sphagnum peat.

\section{UB-2193. 638 to $646 \mathrm{~cm}$}

$6645 \pm \mathbf{1 0 0}$
$\delta^{13} C=-26.3 \%$ o

Woody peat. Marked expansion of alder curve and marked increase of heaths.

\section{UB-2194. 742 to $750 \mathrm{~cm}$}

$$
\begin{array}{r}
\mathbf{8 0 1 0} \pm \mathbf{9 5} \\
\delta^{13} C=-27.0 \%
\end{array}
$$

Woody reedswamp peat. Rational border of oak and elm.

$$
\begin{array}{rr}
\text { UB-2195. } 814 \text { to } 822 \mathrm{~cm} & \mathbf{8 6 9 0} \pm \mathbf{5 0} \\
\delta^{13} C=-27.2 \%
\end{array}
$$

Woody reedswamp peat. Marked rise of hazel curve and fall of birch curve.

\section{UB-2196. 870 to $880 \mathrm{~cm}$}

$$
\begin{array}{r}
\mathbf{8 5 2 0} \pm \mathbf{6 0} \\
\delta^{13} C=-26.9 \% \text { }
\end{array}
$$

Woody peat. Immediately above change from clay to wood peat; base of organic deposits. Contamination by younger acids is suspected. General Comment (RAL): two parallel cores were taken using Jowsey sampler, $4 \mathrm{~cm}$ diam, for pollen analysis and radiocarbon dating. Radio- 
carbon samples taken mainly at levels of important vegetational change with additional samples, in order to estimate deposition rate more accurately. Results are comparable with age determinations for similar vegetational changes elsewhere in Northern Ireland (Smith \& Pilcher, 1973). Date for rational border of hazel pollen (UB-2195) is similar to determinations from Altnahinch, Co Antrim and Meenadoan, Co Tyrone (UB-2136, this list) but later than E coast site of Roddan's Port, Co Down. Date for rational border of oak and elm (UB-2194) is similar to determinations from Altnahinch, Co Antrim, Ballynagilly, Co Tyrone and Sluggan, Co Antrim (Smith \& Pilcher, 1973). Date for rational border of alder (UB-2193) is similar to Altnahinch, Co Antrim and Sluggan, Co Antrim, but later than Ringeneil Quay, Co Down (Morrison, 1961) and earlier than Beaghmore, Co Tyrone and Meenadoan, Co Tyrone (UB-2111, this list). Elm decline at $4595 \pm 85$ (UB-2191) is later than most in North of Ireland but similar to Meenadoan, Co Tyrone (UB2110, this list) and Slieve Gallion, Co Tyrone (Smith \& Pilcher, 1973). Date for pine decline of $4025 \pm 85$ (UB-2190) is consistent with other sites in Northern Ireland and further supports synchroneity of this vegetation change.

\section{Meenadoan Bog series, Co Tyrone}

Samples from raised bog in Meenadoan Td $19 \mathrm{~km}$ W of Omagh, Co Tyrone (54 $35^{\prime} \mathrm{N}, 7^{\circ} 38^{\prime} \mathrm{W}$, IGR: H245717) alt, 215m. Coll Apr 1976 by RAL, JRP and P Bell. Subm Oct 1976 by RAL. Samples received 'A' fraction pretreatment and depths were measured from present bog surface. Pollen percentages are of total land pollen.

UB-2108. 406 to $422 \mathrm{~cm}$

$3335 \pm 110$

Sphagnum peat.

$$
\delta^{13} C=-26.0 \%
$$

\section{UB-2109. 478 to $498 \mathrm{~cm}$}

$$
\begin{array}{r}
4020 \pm 125 \\
\delta^{13} C=-25.2 \% \text { o }
\end{array}
$$
pollen.

Sphagnum peat. Decline of pine pollen and 2nd decline of elm

UB-2110. 558 to $578 \mathrm{~cm}$

$$
\begin{array}{r}
4810 \pm 125 \\
\delta^{13} C=-23.8 \% \%
\end{array}
$$

Sphagnum peat. Marked decline of elm pollen and 1st cereal and plantain pollen.

UB-2111. 702 to $718 \mathrm{~cm}$

Sphagnum peat. Marked expansion of alder curve.

\section{UB-2112. 806 to $822 \mathrm{~cm}$}

Sphagnum peat. Beginning of oak curve.
$5915 \pm 120$

$\delta^{13} C=-25.5 \%$

$7280 \pm 110$

$\delta^{13} C=-25.3 \%$ 
UB-2135. 260 to $286 \mathrm{~cm}$

Sphagnum peat.

UB-2136. 1054 to $1070 \mathrm{~cm}$

$8760 \pm 150$

$\delta^{13} C=-25.4 \%$ o

Reedswamp peat. Marked rise of hazel curve and fall of birch and willow curve. Decline in total tree pollen.

UB-2137. 1078 to $1094 \mathrm{~cm}$

$9015 \pm 335$

$\delta^{1 s} \mathrm{C}=-23.4 \%$

Reedswamp peat. Expansion of birch from ca $10 \%$ to ca $50 \%$ and decline in juniper from ca $50 \%$ to ca $10 \%$.

UB-2139. 1194 to $1202 \mathrm{~cm}$

$11,670 \pm 205$

Soft fibrous detritus mud. Upper part of Zone II (Jessen, 1949), peak of sedge pollen of ca $30 \%$.

UB-2140. 1202 to $1218 \mathrm{~cm}$

$11,790 \pm 250$

$\delta^{13} C=-22.0^{\circ} \%$

Soft fibrous detritus mud. Peaks in birch of ca $10 \%$ and grass of ca $50 \%$.

UB-2141. 1226 to $1242 \mathrm{~cm}$

$12,160 \pm 370$

Soft fibrous detritus mud. Middle of Zone II (Jessen, 1949). High percentages of grass and sedges.

UB-2142. 1250 to $1260 \mathrm{~cm}$

$11,440 \pm 185$

Soft fibrous detritus mud. Lower part of Zone II (Jessen, 1949).

General Comment (RAL): two parallel cores were taken using Jowsey sampler, $4 \mathrm{~cm}$ diam, for pollen analysis and radiocarbon dating. Samples for radiocarbon dating were taken mainly at levels of significant vegetational change. Results are comparable with age determinations for similar vegetational changes elsewhere in Northern Ireland (Smith \& Pilcher, 1973). Pine decline date of $4020 \pm 125$ (UB-2109) agrees with other sites in Northern Ireland. Date for elm decline of $4810 \pm 125$ (UB2110 ) comes to younger end of distribution given by Smith \& Pilcher and is similar to Garry Bog; Sleive Gallion, Co Tyrone and Gortcorbies, Co Londonderry. Date for rational border for alder was $5915 \pm 120$ (UB2111), similar to Beaghmore, Co Tyrone but later than E coast sites of Ringeneil Quay, Co Down (Morrison, 1961), Lacken, Co Down (UB-803, R, 1975, v 17, p 232) and Carrivmoragh, Co Down, (UB-872, R, 1975, v 17, p 234; Holland, 1975). But Meenadoan Bog date is earlier than Ballynagilly and Beaghmore, Co Tyrone. Rational border for oak was dated as $7280 \pm 110$ (UB-2112), similar to Carrivmoragh, Co Down (Holland, 1975), but later than other sites in Northern Ireland. Rational border for hazel was dated as $8760 \pm 150$ (UB-2136), similar to Garry Bog 
and Altnahinch, Co Antrim, but later than Roddan's Port, Co Down. Expansion of birch, prior to rational border for hazel, dated at $9015 \pm$ 335 (UB-2137) is similar to Ballynagilly, Co Tyrone (UB-260, R, 1971, v 13, p 112) and Sluggan, Co Antrim (UB-443, R, 1971, v 13, p 454). Date of 11,670 \pm 205 (UB-2139) for end of Zone II (Jessen, 1949) is similar to Roddan's Port, Co Down, (UB-401, R, 1971, v 13, p 464). Start of Zone II was dated to $11,440 \pm 185$ (UB-2142) but sample $10 \mathrm{~cm}$ above this gave date of $12,160 \pm 270$ (UB-2141). UB-2142 may have been contaminated by younger humic acids (Dresser, 1970) and therefore start of Zone II may be similar age to Sluggan, Co Antrim (UB-299, R, 1971, v 13, p 466) where it was dated to $12,360 \pm 165$.

\section{UB-937. Bann Estuary}

$\mathbf{5 3 1 5} \pm \mathbf{1 3 5}$

$\delta^{13} C=-25.5 \%$

Sample of leaves and moss in silt from estuary at Castlerock Td, $2 \mathrm{~km}$ E of Castlerock, Co Londonderry $\left(55^{\circ} 10^{\prime} \mathrm{N}, 6^{\circ} 45^{\prime} \mathrm{W}\right.$, IGR: C 800354 ) alt, $1 \mathrm{~m}$. Sample coll 1973 and subm 1975 by A C Hamilton, School Biol \& Environmental Sci, New Univ Ulster, Coleraine. Leaf (id as oak by ACH) extraction from sample 230 to $280 \mathrm{~cm}$ below cliff top on bank of R Articlave ca $100 \mathrm{~m}$ from river mouth. Comment (ACH): sample comes from leaf bed in silt sandwiched between sand layers. Site is of considerable palaeobotanic importance because of its rich content of leaves and bryophytes. Fossil beetles are also present. Ca $20 \mathrm{sp}$ of moss have been id so far, including some previously unrecorded from Quaternary deposits in British Isles.

\section{Mountsandel Kettle Hole series, Coleraine}

Peat samples from kettle hole at Mountsandel $2 \mathrm{~km} \mathrm{~S}$ of Coleraine, Co Londonderry (57 $7^{\prime} \mathrm{N}, 6^{\circ} 40^{\prime} \mathrm{W}$, IGR: C853307) alt, 30m. Coll and subm 1975 by ACH.

\section{UB-2013. 122 to $142 \mathrm{~cm}$}

$12,175 \pm 90$

Sample from basal organic layer. 'A' fraction.

$$
\delta^{13} \mathrm{C}=-18.9 \%
$$

UB-2014. 58 to $65 \mathrm{~cm}$

$$
\begin{array}{r}
\mathbf{5 2 8 0} \pm \mathbf{6 0} \\
\delta^{13} C=-26.4 \%
\end{array}
$$

Peat. 'A' fraction.

\section{UB-2015. 42 to $49 \mathrm{~cm}$}

$$
7210 \pm 100
$$

Peat. 'A' fraction.

$$
\delta^{13} \mathrm{C}=-26.1 \%
$$

\section{UB-2016. 26 to $33 \mathrm{~cm}$}

$$
\begin{array}{r}
\mathbf{6 7 3 0} \pm \mathbf{1 0 5} \\
\delta^{13} \mathrm{C}=-25.5 \%
\end{array}
$$

Peat. 'A' fraction. Comment (ACH): kettle hole on sands and gravels date to ice retreat from Armoy-Ballymoney moraines of Scottish readvance. Sediments show 4-fold division into clay (base), peat, clay and 
peat. Pollen analyses and ${ }^{14} \mathrm{C}$ determination UB-2013 shows that 1st 3 strata are late glacial. Late-glacial pollen diagram is remarkable for high Juniperus values. Pollen analyses and remaining ${ }^{14} \mathrm{C}$ determinations indicate that upper peat is of Atlantic age and that there is hiatus in sediment accumulation in basin between late glacial and Atlantic period. Samples provide evidence of change to moister climate at Boreal/Atlantic boundary.

\section{The Berwyn mountain series, North Wales}

Peat samples from blanket bog on Berwyn Mts, ca $8 \mathrm{~km}$ N of Llanrhoeadr in Clwyd, Wales (52 $52^{\prime} \mathrm{N}, 3^{\circ} 23^{\prime} \mathrm{W}$ ). Coll and subm 1975 by J L Bostock, Dept Botany, Manchester Univ, England.

\section{UB-997. R C 1, 143 to $144 \mathrm{~cm}$}

$$
\begin{array}{r}
1595 \pm 40 \\
\delta^{13} C=-26.2 \% \text { o }
\end{array}
$$

'F' fraction of peat in sec $157 \mathrm{~cm}$ deep, alt $821 \mathrm{~m}$, Moelsych. Eriophorum vaginatum peat with Sphagnum 'acutifolia' taken above very compacted basal peat layers from summit-ridge non-pool-system peat. Comment (JLB): sample provides comparison of peat accumulation rate with R C 2 pool-system peat from same depth, referable to $98 \mathrm{~cm}$ depth on main Berwyn pollen diagram from Trumfelen pool-system.

UB-998. R C 2, 142 to $143 \mathrm{~cm}$

$1995 \pm 70$

$\delta^{13} C=-25.5 \%$

' $\mathrm{F}$ ' fraction of peat from $310 \mathrm{~cm}$ deep peat face, alt $649 \mathrm{~m}$ in Ygodor II pool-system. Taken from central sphagnum acutifolia rich peat, crossmatched by pollen analysis to main Berwyn pollen diagram at same depth. Comment (JLB): this point $10 \mathrm{~cm}$ below increase in pollen of grazing, arable farming, open woodland indicator sp and decrease in scrub $\mathrm{sp}$ is referable to Roman period.

UB-999. R C 3, 35 to $36 \mathrm{~cm}$

$195 \pm 60$

$\delta^{13} \mathrm{C}=-24.9 \%$

'F' fraction of peat from face as in UB-998. Sample was taken to date changes in macrofossil composition of slow forming upper hummock peats, leading in this face to loss of Sphagnum acutifolia at $24 \mathrm{~cm}$ depth. Comment (JLB): rate of peat formation from this point to surface indicates that all contaminating material had not been removed.

UB-1000. R C 4, 240 to $241.5 \mathrm{~cm}$

$$
\begin{array}{r}
\mathbf{3 4 8 0} \pm \mathbf{8 0} \\
\delta^{13} C=-24.9 \%
\end{array}
$$

' $F$ ' fraction of peat from peat face as in UB-998 and -999. Taken from slower forming less Sphagnum acutifolia-rich lower peat. Comment (JLB): sample, cross-matched to 250 to $252 \mathrm{~cm}$ on main Berwyn pollen diagram, is $20 \mathrm{~cm}$ below Late Bronze age major expansion of arable and pastoral agriculture into woodlands of area, after which arboreal pollen levels never recovered their former value, Tilia and Ulnus severely de- 
clining, and soil impoverishment suggested by increase in levels of heathland sp and Betula pollens.

General Comment (JLB): dates made to calculate rate of peat formation in various peat 'Zones' id by macro-fossil analysis, in study of build-up and erosion of pool-system peat in Berwyn blanket bog. Dates establish lasting importance of Late Bronze age and Roman agricultural interference on vegetation of area.

\section{Rahona series, Co Clare, Eire}

Samples from forest on fore-shore at Rahona, $25 \mathrm{~km} \mathrm{SW}$ of Carrigahold, Co Clare (52० $35^{\prime} \mathrm{N}, 9^{\circ} 43^{\prime} \mathrm{W}$, IGR: Q833494) alt, between tide marks. Coll and subm 1976 by G F Mitchell, Trinity Coll, Dublin.

UB-2093. CLR-1

$4185 \pm 50$

Cellulose extracted from oak wood sample. Growth position on foreshore between tide marks.

\section{UB-2094. CLR-2}

$$
\begin{array}{r}
\mathbf{3 9 3 5} \pm \mathbf{8 0} \\
\delta^{13} C=-27.7 \%
\end{array}
$$

Wood peat sample from foreshore between tide marks. Acid pretreatment.

General Comment (GFM): samples coll as part of program of dating 'submerged forests' on coasts of Ireland. Dates same as those from other 'young submerged forests' in Ireland (Mitchell, 1976, p 182).

\section{UB-2095. Rossbeg Harbour}

$$
\begin{array}{r}
6995 \pm 105 \\
\delta^{13} C=-26.8 \%
\end{array}
$$

Phragmites peat sample from peat between tide marks at Rossbeg Harbour 9km NW Ardara, Co Donegal (54 49' N, $8^{\circ} 32^{\prime}$ W, IGR: G661963) alt, between tide marks. Coll and subm 1976 by GFM. 'A' fraction. Comment (GFM): sample coll as part of program of dating 'submerged forests' on coasts of Ireland. Date same as those from other 'old submerged forests' in Ireland, and indicates time when postglacial eustatic rise in sea-level reached present level (Mitchell, 1976, p 132-133).

\section{UB-2096. Loughros Head}

$4205 \pm 80$

Peat sample at base of blanket peat overlying blown sand of fossil dune system at Loughros Head, $8 \mathrm{~km}$ W Ardara, Co Donegal $\left(54^{\circ} 46^{\prime} \mathrm{N}\right.$, $8^{\circ} 33^{\prime}$ W, IGR: G650928) alt, 30m. Coll and subm 1976 by GFM. 'A' fraction. Comment (GFM): sample indicates date at which blanket peat started to form, agreeing with similar samples, and date by which extensive system of sand dune become immobile. 
REFERENCES

Bersu, G, 1977, Three Iron age round houses in the Isle of Man: Pub Manx Museum and National Trust, Isle of Man.

Dresser, P Q, 1970, A study of sampling and pretreatment of materials for radiocarbon dating: PhD thesis, Queen's Univ, Belfast, Northern Ireland.

Holland, S M, 1975, Pollen analytical study concerning settlements and early ecology in Co Down, Northern Ireland: PhD thesis, Queen's Univ, Belfast, Northern Ireland.

Jessen, K, 1949, Studies in late Quaternary deposits and flora history of Ireland: Royal Irish Acad Proc, v 52B, p 85-290.

McNeill, T, 1975-76, Excavation report: AYIA, p 6-7.

Mitchell, G F, 1976, The Irish Landscape: Collins (London), p 132-133.

Morrison, M E S, 1961, The palynology of Ringeneil Quay, a new Mesolithic site in Co Down, Northern Ireland: Royal Irish Acad Proc, v 61C, p 171-182.

Simpson, G, 1976, A barrow cemetery of the second millennium BC at Tallington, Lincolnshire, England: Prehistorical Soc Proc, v 42, p 215-239.

Smith, A G and Pilcher, J R, 1973, Radiocarbon dates and vegetational history of the British Isles: New Phytol, v 72, p 903-914. 